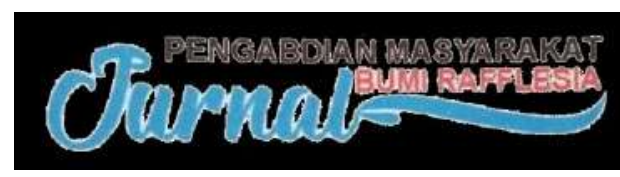

\title{
PENDAMPINGAN PERIJINAN UMKM DI KABUPATEN PRINGSEWU
}

\author{
Arum Arupi Kusnindar, S.E, MBA \\ STIE Muhammadiyah Pringsewu Lampung \\ arumarupi@stiemuh-pringsewu.ac.id \\ Mahasiswa KKN Program Pengembangan Kewirausahaan (PPK) \\ STIE Muhammadiyah Pringsewu Lampung
}

\begin{abstract}
ABSTRAK
Perijinan merupakan syarat utama legalitas suatu unit usaha. Legalitas akan di perlukan bagi unit usaha untuk dapat berkembang menjadi unit usaha yang lebih besar. Legalitas akan di perlukan untuk pengurusan kredit perbankan, maupun proses yang lain seperti NIB (Nomer Induk Berusaha).

Perijinan terendah bagi UMKM adalah IUMK (Ijin Usaha Mikro Kecil) yang di keluarkan oleh Kecamatan. Untuk UMKM yang bergerak di bidang kuliner setelah IUMK harus diikuti dengan ijin edar yaitu PIRT (Perijinan Industri Rumah Tangga)

Di Kabupaten Pringsewu, sebagian besar UMKM belum mempunyai ijin usaha. Kalaupun ada ijin hanya berupa surat ijin usaha pekon. Karena belum memiliki IUMK dan PIRT banyak produk kuliner belum dapat di pasarkan ke toko makanan besar.

Pengabdian masyarakat dilakukan pada kelompok wirausha yang terdiri dari 5 pengusaha dalam bidang kuliner. Lokasi mitra UMKM berada di Kecamatan Pringsewu, Kabupaten Pringsewu. Pengabdian dilakukan selama 1 bulan, dari tanggal 25 September sampai dengan 25 Agustus 2019.

Metode pelaksanaan berupa pendampingan dari proses soasilisasi syarat dan ijin apa saja yang dibutuhkan oleh UMKM, Mengumpulkan persyaratan dan Pengajuan Ijin.

Hasil dari pengabdian ini, berupa ijin usaha IUMK dan PIRT yang terbit secara legal dan dapat di pergunakan oleh mitra serta pengetahuan yang di dapatkan mitra mengenai proses perijinan yang harus dilakukan.
\end{abstract}

Kata Kunci : ijin, PIRT, IUMK

\section{PENDAHULUAN}

Pringsewu merupakan kabupaten yang menjadi ikon perdagangan. Kabupaten Pringsewu terdiri dari 9 kecamatan, Dengan penduduk sebanyak 73.341 orang Kecamatan Pringsewu menjadi kecamatan yang terpadat. Begitu pula dengan jumlah UMKM yang ada di Kecamatn Pringsewu adalah jumlah terbesar di banding kecamatan lain. Dengan jumlah UMKM sebanyak 1332 unit usaha, yang terdiri dari
1059 unit sauah mikro, 244 unit usaha kecil dan 29 unit usaha menengah. Dari data tersebut 79 bergerak di bidang jasa, 739 unit usaha perdagangan dan 522 merupakan industri.

Pringsewu mempunyai luas wilayah $53.29 \mathrm{~km} 2$ dan dengan 1332 unit, maka per $1 \mathrm{~km} 2$ terdapat 25 UMKM. Wilayah kecamatan pringsewu jika di gambarkan dalam peta terlihat sebagai berikut:

Peta Wilayah Kabupaten Pringsewu 


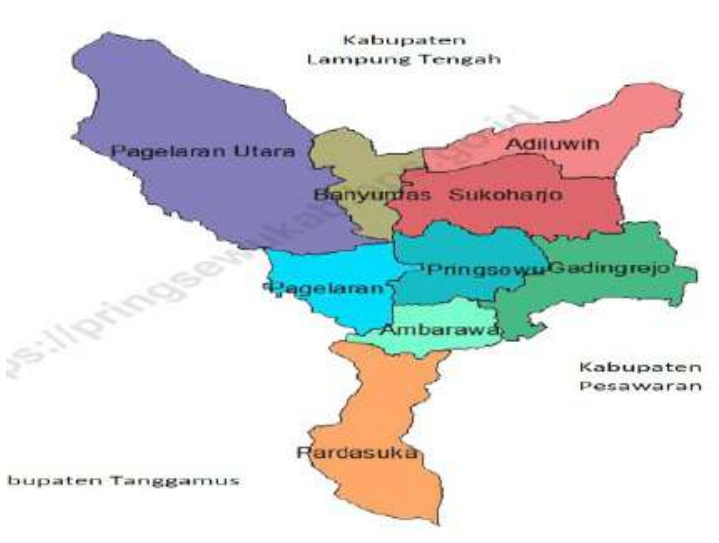

Dalam penelitian Kusnindar (2018) mengenai profil UMKM di kabupaten pringsewu, berhasil mengelompokan UMKM di Kabupaten Pringsewu ke dalam berdasarkan kinerja, kecamatan Pringsewu dalam profil kecamatan yang mempunyai mempunyai kinerja tinggi. Artinya UMKM mempunyai omset lebih tinggi dari rata - rata omset UMKM sekabupaten Pringsewu dan juga mempunyai serapan tenaga kerja yang lebih tinggi atau sama dengan rata rata serapan tenaga kerja sekabupaten Pringsewu.

Analisis situasi yang dilakukan pada UMKM di Kabupaten Pringsewu menunjukan hal sebagai berikut:

Tabel 1. Analisis situasi UMKM Kec.Pringsewu

\begin{tabular}{|c|c|c|c|c|}
\hline$\stackrel{\stackrel{\sigma}{\vec{\Xi}}}{\stackrel{\sigma}{\Xi}}$ & 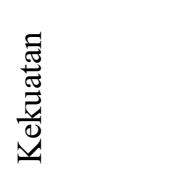 & 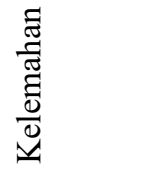 & 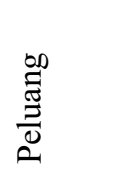 & 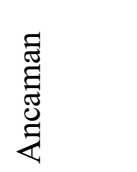 \\
\hline $\begin{array}{l}\text { Omset } \\
\text { Tinggi, } \\
\text { Serapa } \\
\mathrm{n} \\
\text { Tenaga } \\
\text { Kerja } \\
\text { Tinggi }\end{array}$ & $\begin{array}{l}\text { Tingkat } \\
\text { upah masih } \\
\text { rendah, } \\
\text { Inovasi } \\
\text { dan } \\
\text { kreatifitas } \\
\text { tinggi, } \\
\text { bermental } \\
\text { tangguh. } \\
\text { Modal }\end{array}$ & $\begin{array}{l}\text { SDM } \\
\text { dalam } \\
\text { manajem } \\
\text { en dan } \\
\text { keuangan } \\
\text {, Teknik } \\
\text { produksi }\end{array}$ & $\begin{array}{l}\text { Perputa } \\
\text { ran } \\
\text { modal } \\
\text { sangat } \\
\text { tinggi } \\
\text { dan } \\
\text { cepat, } \\
\text { Keama } \\
\text { nan, } \\
\text { Sentra }\end{array}$ & $\begin{array}{l}\text { Skill } \\
\text { SDM } \\
\text { kurang } \\
\text { memadai } \\
\text {, Online } \\
\text { market }\end{array}$ \\
\hline
\end{tabular}

\begin{tabular}{|l|l|l|l|l|}
\hline & lebih kuat & $\begin{array}{l}\text { Perdag } \\
\text { angan }\end{array}$ & \\
\hline
\end{tabular}

Dari keseluruhan UMKM yang ada di Kabupaten Pringsewu hanya $20 \%$ yang sudah mempunyai ijin edar atau PIRT dan IUMK. Tanpa PIRT dan IUMK, UMKM tidak bisa menjual produk yang mereka miliki dan tidak mempunyai perlindungan hukum dan juga tidak bisa membuat NIB (Nomer Induk berusaha). Sedangkan tidak semua UMKM mengetahui persyaratan dan proses pengurusan PIRT.

Pemerintah telah menetapkan Peraturan Presiden Nomor 98 tahun 2014 tentang perizinan untuk usaha mikro dan kecil yang bertujuan untuk memberikan kepastian hukum dan sarana pemberdayaan bagi Pelaku Usaha Mikro dan Kecil (PUMK) dalam mengembangkan usahanya. Selain itu, dalam pengurusan prosedur IUMK setelah keluar PERPRES menjadi lebih sederhana, mudah, dan cepat sehingga menguntungkan bagi pelaku usaha.

\section{TUJUAN DAN MANFAAT}

Tujuan dan manfaat dari kegiatan pendampingan ini adalah:

1. Memerikan sosialisasi mengenai ijin - ijin yang di butuhkan oleh UMKM, manfaat dan kegunaan ijin ijin tersebut

2. Memberikan sosialisasi mengani syarat dan proses yang harus dilakukan untuk mendpatkan ijin

3. Memberikan pendampingan dalam proses pengurusan ijin IUMK dan PIRT

4. UMKM akan mendapatkan ijin usaha sehingga mereka dapat menaikan kelas Usaha mereka 
setingkat lebih tinggi, diakui oleh Negara dan mendapat perlindungan hukum

\section{METODE PELAKSANAAN}

Kegiatan dilakukan dalam beberapa tahapan yaitu:

1. Melakukan sosialisasi mengenai ijin ijin apa saja yang diperlukan oleh UMKM, syarat serta proses pengajuannya

2. Melakukan pendampingan proses pengajuan ijin

3. Bekerjasama dengan dinas kesehatan berkaitan dengan ijin PIRT

4. Melakukan evaluasi pelaksanaan pengabdian

\section{PELAKSANAAN}

\section{Kegiatan Sosialisasi}

Kegiatan sosialisasi dilakukan pada beberapa kelompok UMKM dengan daftar UMKM sebagai berikut:

Tabel 2. UMKM Sasaran Pengabdian

Masyarakat

\begin{tabular}{|l|l|l|l|}
\hline No & Nama UKM & Nama Pemilik & $\begin{array}{l}\text { Ijin yang } \\
\text { tidak } \\
\text { dimiliki }\end{array}$ \\
\hline 1 & $\begin{array}{l}\text { Brownies } \\
\text { kering }\end{array}$ & $\begin{array}{l}\text { Evi } \\
\text { Septikasari }\end{array}$ & $\begin{array}{l}\text { IUMK, } \\
\text { PIRT }\end{array}$ \\
\hline 2 & Evi Riauda & Tusuk Gigi & $\begin{array}{l}\text { IUMK, } \\
\text { PIRT }\end{array}$ \\
\hline 3 & Kue Kering & MM & $\begin{array}{l}\text { IUMK, } \\
\text { PIRT }\end{array}$ \\
\hline 4 & Kue Ketawa & Eka Julianti & $\begin{array}{l}\text { IUMK, } \\
\text { PIRT }\end{array}$ \\
\hline 5 & $\begin{array}{l}\text { Pangsit } \\
\text { Crispy }\end{array}$ & Amira & $\begin{array}{l}\text { IUMK, } \\
\text { PIRT }\end{array}$ \\
\hline
\end{tabular}

UMKM yang menjadi mitra dalam kegiatan pengabdian ini bergerak pada industri kuliner.

\section{Produk mereka tampak pada foto di bawah ini:}
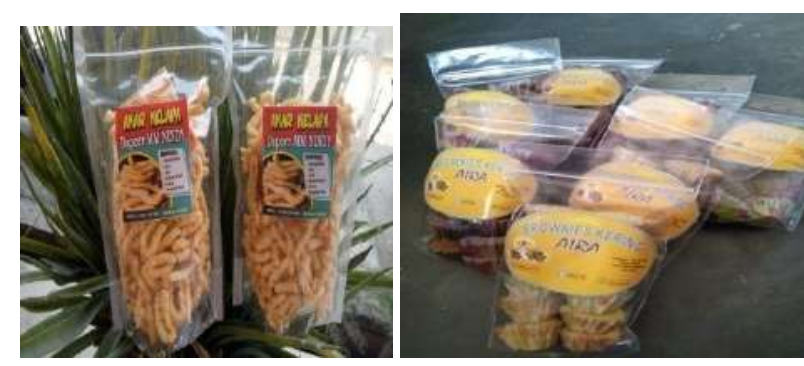

MM Nindy

Bownies - Evi S
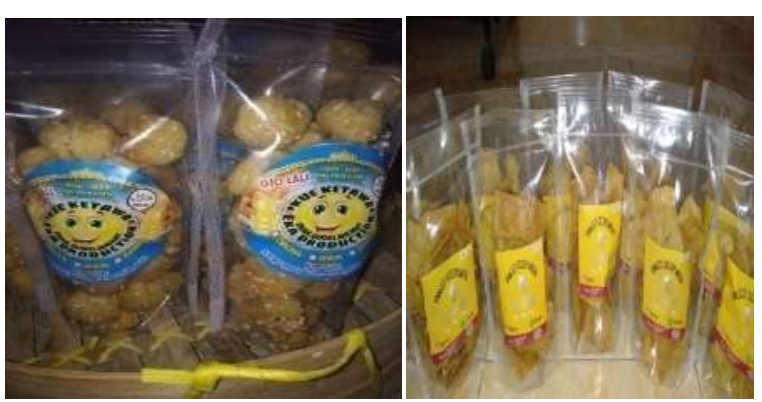

Kue Ketawa - Eka

Pangsit Crispy - Amira

\section{Materi Sosialisasi}

Materi sosialisasi terdiri dari

1. Syarat mendapatkan IUMK

Untuk mendapatkan IUMK, pelaku usaha harus mempersiapkan:
a. Melampirkan surat pengantar dari RT
b. Melampirkan surat pengantar dari kepala pekon/dusun
c. Memiliki Kartu Tanda Penduduk (KTP) setempat atau KTP Pringsewu
d. Memiliki Kartu Keluarga.
e. Memiliki bukti pembayaran Pajak bumi dan bangunan (PBB)
f. Melampirkan Pas Photo berwarna ukuran $4 \times 6 \mathrm{~cm} 2$ lembar.


g. Mengisi formulir IUMK yang telah tersedia di kantor Kecamatan Pringsewu.

2. Keuntungan mempunyai IUMK

Keuntungan mempunyai IUMK sebagai berikut

a. Mendapatkan kepastian perlindungan hukum dalam usaha sesuai dengan lokasi yang sudah ditetapkan.

b. Mendapatkan kemudahan dalam pemberdayaan baik dari pusat, provinsi maupun dari daerah.

c. Mendapatkan kemudahan dalam mengakses pembiayaan ke berbagai lembaga keuangan bank maupun non-bank.

d. Mendapatkan pendampingan untuk pengembangan usaha yang lebih besar.

e. Mendapatkan pengakuan yang sah dari berbagai pihak atas izin yang dimiliki dan dapat dipertanggungjawabkan secara hukum.

f. Mendorong para pelaku bisnis UMKM untuk sadar pajak, sehingga bisa bermanfaat untuk kemajuan usahanya.

g. Menjadi nilai plus bisnis UMKM lain yang tidak memiliki IUMK.

h. IUMK menjadi syarat wajib untuk ijin-ijin lain seperti BPPOM, PIRT dan NIB.

\section{Dokumentasi saat kegiatan sosialisasi:}

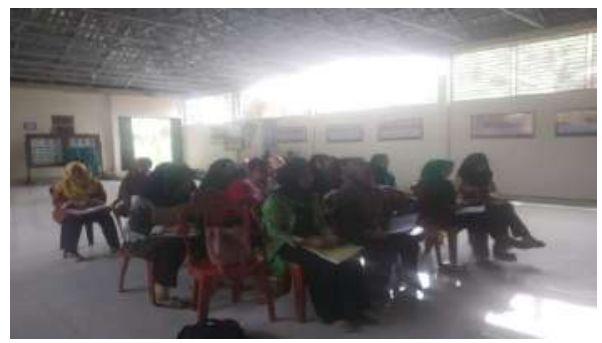

Dokumentasi IUMK yang sudah terproses

IUMK Evi Ruaida

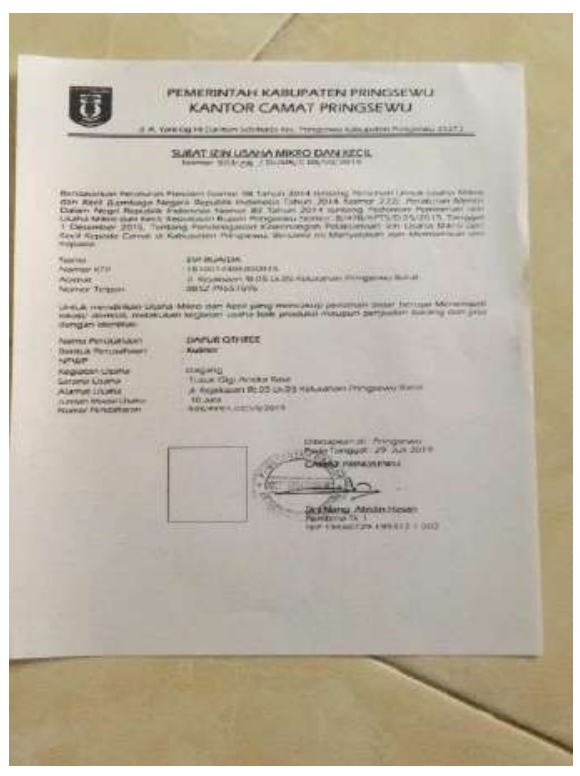

\section{IUMK Amira Pangsit Crispy}

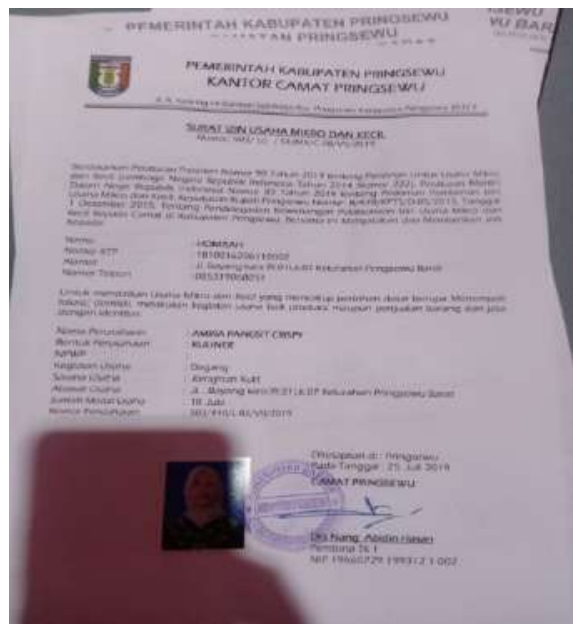

3. Persyaratan mengurus PIRT

Setelah mendapatkan IUMK, selanjutnya pelaku usaha yang mempunyai produk yang awet (lebih dari 7 hari) dan merupakan industri kuliner wajib mengurus PIRT. Untuk mendapatkan PIRT syaratnya adalah:

a. Melampirkan IUMK

b. Melampirkan LH, LH merupakan surat keterangan layak pangan dari puskemas setempat. Untuk mendapatkan LH, pelaku usaha harus mengajukan permohonan survey ke puskemas setempat. Petugas 
puskemas akan melakukan survey tempat produksi apakah sudah memenuhi standard dan kriteria yang termasuk sampel produk tidak memakai bahan bahan yang berbahaya.

c. Sertifikat Penyuluhan Keamanan Pangan (PKP). PKP bisa di dapatkan jika pelaku usaha sudah mengikuti pelatihan yang di selenggarakan oleh Dinas Kesehatan. Kegiatan PKP dilakukan pada tanggal 22 Agustus 2019.

d. Melampirkan formulir pengajuan PIRT yang sudah di isi dengan lengkap

e. Mengajukan semua berkas ke dinas kesehatan. Dinas Kesehatan akan melakukan survey untuk menentukan apakah usaha layak mendapat PIRT atau tidak. Jika di nilai layak, maka PIRT akan di terbitkan oleh Dinas Kesehatan.

Dokumentasi saat sosialisasi PKP oleh Dinas

\section{Kesehatan}

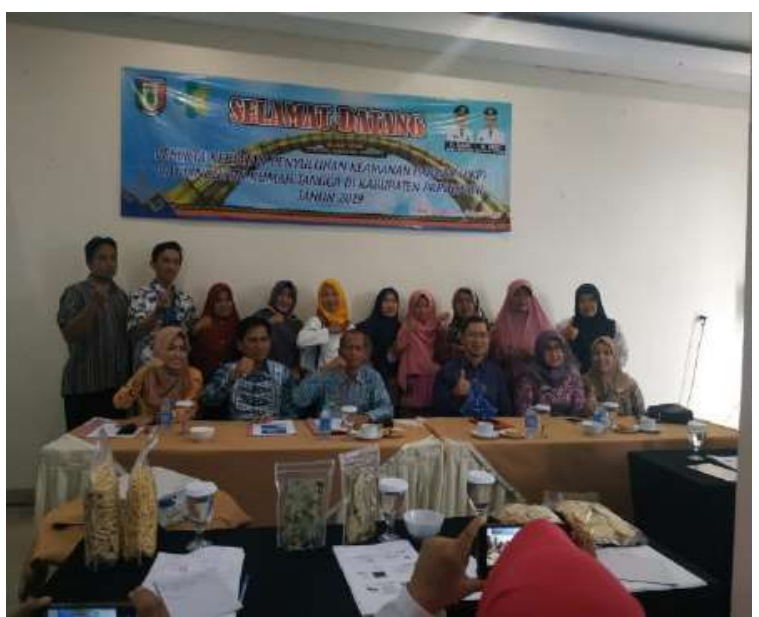

DOKUMENTASI SERTIFIKAT PKP

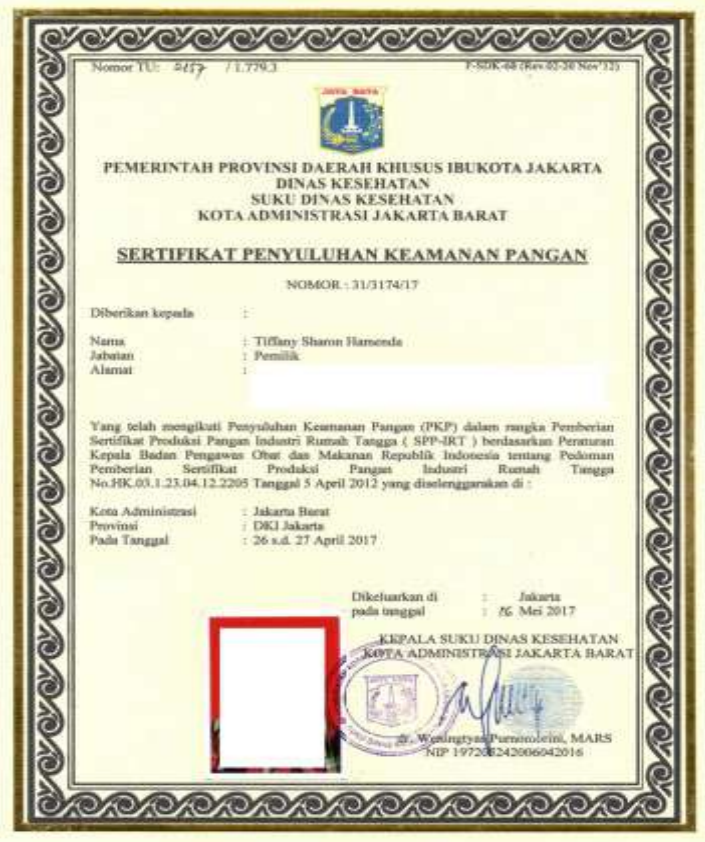

\section{Kegiatan Pendampingan}

Kegiatan pendampingan dilakukan dalam beberapa tahapan yaitu:

1. Bekerjasama dengan pelaku usaha untuk mengumpulkan syarat syarat IUMK

2. Mendampingi pelaku usaha mendapatkan surat pengantar dari pekon

3. Mendampingi pelaku usaha mendapatkan IUMK di kantor Kecamatan

4. Mendampingi pelaku usaha mengajukan permohonan LH ke puskemas setempat

5. Mendampingi melakuakn pelaku usaha saat dilakukan survey dari petugas puskemas

6. Membantu pelaku usaha melaksanakan semua yang di sarankan dari petugas puskemas berkaitan dengan LH (kondisi keamanan dan kesehatan tempat produksi) serta keamanan dan kesehatan pangan.

7. Mendaftarkan pelaku usaha pada kegiatan penyuluhan pangan yang di adakan oleh Dinas Kesehatan. Pelaksanaan penyuluhan keamanan pangan (PKP) dilaksanakan pada 
tanggal 22 Agustus 2019. Dalam kegiatan ini di ajarkan beberapa hal yaitu:

a. Peraturan perundang-undangan di bidang pangan

b. Keamanan dan Mutu Pangan

c. Teknologi Proses Pengolahan Pangan

d. Prosedur Operasi Sanitasi yang Standar (SSOP)

e. Cara Produksi Pangan yang Baik untuk Industri Rumah Tangga (CPPB-IRT)

f. Penggunaan Bahan Tambahan Pangan (BTP)

g. Persyaratan Label dan Iklan Pangan

8. Mengumpulkan berkas berkas untuk mendaftarkan pelaku usaha ke Dinas Kesehatan sebagai syarat mendapatkan PIRT

Dokumentasi saat pengumpulan dan verifikasi berkas

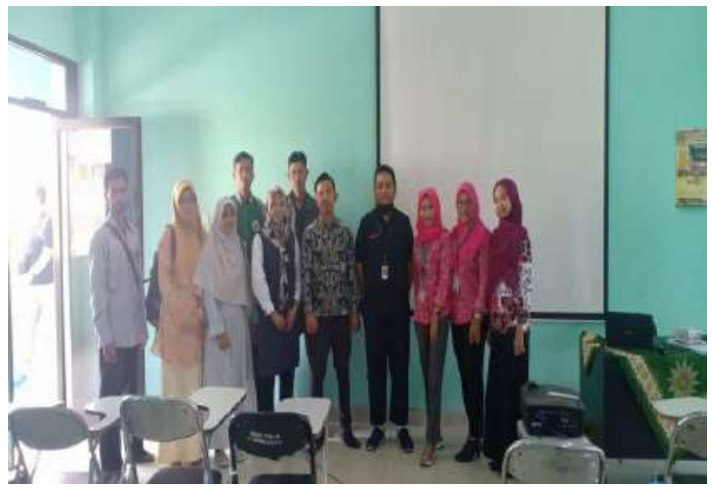

9. Mendaptkan jadwal survey dari dinas kesehatan dan mendapingi pelaku usaha saat dilakukan survey

10. Membantu pelaku usaha melaksanakansemua masukan dari Dinas Kesehatan terkait hasil survey lokasi produksi dan produk

11. Mendampingi pelaku usaha saat mengambil hasil dan nomer PIRT

\section{FOTO FORMULIR PIRT YANG HARUS DISI}

Yang betterda tangan da bawah hi kami Pemilik / Penanggung Jaweb Perusahaan Fanga Industi Rumah Tangga :

Nama

Tempat, Tgl Lahi

Alanat

Nomo: TeloponhAP

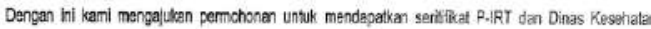
Kabupaten Pringsemu, bersama ini kani lempintan :

1. Folokopi Kartu Tanda Penduduk. (KTP) yang masih bertaku

2. Biodata Perusahlaan Pangan Industi Rumah Tangga

3. Fotokopi Serfikat Pernyuluten Kesmanan Pangen (PKP)

4. Fotokopi Sattikat Laik Hyoune (LH)

5. Surnt keterangan usaha dari pekon

6. Survei Lokas

Demikilan sura: permchonan in saya buat dan saya tersoda mentoati peraturan yang berlaht Hormatkami,

Femlik/ Penanggung Javab

Peruschaan Pangan Industri Rumah Tangya

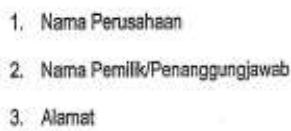

3. Alamat

\section{Nama Jenis Makanan \\ 5. Nama Merk Dagang \\ . Bahan Baku \\ 7. Bahan Tambahan Makanan \\ a. Pewama \\ b. Pengawet \\ c. Dan lain-lain}

8. Bahan Wadah Kemasan

1. Kertas

2. Plastik

3. Kaca

4. Kaleng

5. Bahan Lain

9. Cara Pengolahan

10. Masa Simpen

11. LABEL

Terlampir

\section{HASIL DAN PEMBAHASAN}

Kegiatan pendampingan yang dilakan selama satu bulan mempunyai hasil sebagai berikut: 
1. IUMK (ijin Usaha Mikro Kecil) untuk kelima mitra selesai diproses. Pada akhir masa pengabdian semua mitra sudah memiliki IUMK. Dengan memilku IUMK,, pelaku usaha memiliki syarat minimal sebagai usaha yang legal dan berhak atas kepastian dan perlindungan hukum pembinaan dan pemberdayaan dari dinas terkait. Dalam kepengurusan IUMK, kantor kecamatan sangat kooperatif dan proses tidak menemu permasalahan.

2. Kelima mitra dalam kegiatan sudah mendaftarkan proses LH kepuskesmas setempat. Namun, sampai dengan kegiatan pendampingan selesai dilakukan proses survey dari puskemas belum dilakukan dengan berbagai alasan. Proses pengajuan LH ini menjadi salah satu hambatan dalam pengurusan ijin. Tampak bahwa puskesmas setempat belum sinkron dengan kebijakan pemerintah daerah untuk mempemudah ijin bagi usaha mikro kecil. Dalam proses ini, pengurusan LH menjadi critical point karena lambatnya proses.

3. Pada akhir kegiatan pengabdian, semua mitra sudah mendapatkan sertifikat PKP sebagai salah satu syarat dalam mengurus PIRT. PKP (Penyuluhan Keamanan Pangan) dilakukan oleh Dinas Kesehatan pada tanggal 22 Agustus. Kendala dalam kegiatan ini adalah jarangnya kegiatan ini dilakukan. PKP dilakukan hanya dua kali dalam setahun dan dengan kuota peserta yang terbatas (hanya 50 orang) sehingga dalam setahun hanya 100 UMKM yang bisa terfasilitasi. Dibandingan dengan ratusan jumlah unit usaha yang ada tentu saja tidak mampu memfasilitasi dengan cepat semua
UMKM. Salah satu solusi yang di tawarkan adalah mengikuti kegiatan PKP yang dilakukan oleh kabupaten lain, namun hal ini tidak mudah karena jarak dan biaya.

4. Walaupun pada akhir masa kegiatan pengabdian, PIRT belum dapat terbit karena terkendala surat LH yang belum keluar namun, semua pelaku usaha mitra mempunyai pengetahuan mengenai ijin ijin yang harus dimiliki, keuntungan dan manfaat mempunyai ijin, syarat dan proses yang harus dilakukan untuk mendapatkan ijin serta contact person dari para petugas dinas yang mempunyai kewenangan dalam pengurusan ijin. Diharapkan, pengetahuan yang mereka miliki akan di sebarluaskan ke rekan rekan pelaku usaha yang lain.

\section{KESIMPULAN DAN SARAN}

Kesimpulan yang dapat diambil dari kegiatan pendampingan ini adalah:

1. Ijin merupakan hal mendasar yangharus dilakukan oleh seorang pelaku usaha baik besar maupun kecil. Melalui Peraturan Presiden Nomor 98 tahun 2014 tentang perizinan untuk usaha mikro dan kecil, proses di buat semudah dan secepat mungkin. Untuk Usaha mikro kecil diperlukan IUMK yang bisa di keluarkan oleh Kecamatan, kemudian untuk izin edar diperlukan PIRT.

2. Usaha Mikro dan Kecil yang sudah memiliki IUMK dan PIRT dapat mengembangkan skala usaha dengan menambah penjualan. Produk bisa mereka titipkan ke toko dan gerai besar sehingga 
penjualan akan meningkat dan area pemasaran mereka menjadi lebih luas.

3. Kendala yang di hadapi dalam kegiatan pendampingan ini adalah lambatnya proses pengurusan LH dan PIRT. LH dan PIRT di keluarkan oleh Dinas Kesehatan dan memerlukan proses survey. Karena keterbatasan sumber daya, maka pengajuan yang dilakukan sampai dengan selesainya masa pendampingan (1 bulan) belum juga bisa di proses.

4. Team dosen dan mahasiswa akan tetap melakukan pendampingan sampai dengan LH dan PIRT sudah terbit walaupun waktu yang diberikan selama satu bulan sudah berakhir. Proses pendampingan dilakukan dengna melakukan komunikasi intesif dengna pihak Dinas Kesehatan.

Saran yang bisa di berikan kepada para stakeholders dalam proses pembuatan ijin adalah:

1. Sinkronisasi pemahaman proses percepatan ijin usaha mikro dan kecil. Semangat peraturan presiden ini belum sepenuhnya di pahami dan di laksanakan oleh aparat parat terkait. Sehingga tidak ada kesiapan sumber daya, fasilitas dan sarana pendukung yang lebih baik.

2. Harus di bentuk satuan tugas yang mengevaluasi kemajuan proses perijinan UMKM, serta mengidentifikasi botleneck yang terjadi. Satuan tugas berisi stakeholders dan institusi di luar stakeholders untuk menjaga obyektifitas.

\section{DAFTAR PUSTAKA}

Kabupaten Pringsewu dalam Angka -2017, BPS Kabupaten pringsewu, 2017

Lembaga Pengembangan Perbankan (LPPI) \& BI 2015, Profil Bisnis Usaha Mikro, Kecil danMenengah (UMKM), Jakarta, 2015

USAID Report, 2012, 'A Snapshot of Indonesia Enterpreneurship and Micro, Small and Medium Enterprise Development'.

Rencana Strategik Dinas Perindustrian, Perdagangan, koperais dan UMKM tahun 2016, Diskop dan UMKM Kabupaten Pringsewu, 2016

USAID Report, 2012, 'A Snapshot of Indonesia Enterpreneurship and Micro, Small and Medium Enterprise Development'. 